\title{
Chilling Injury of Sweet Potato Shoots Reduced by Prior Incubation of $\mathrm{H}_{2} \mathrm{O}_{2}$ and $\mathrm{NaCl}$
}

\author{
W.C. Lin* and G.S. Block \\ Pacific Agri-Food Research Centre, Agriculture and Agri-Food Canada, P. O. Box 1000, Agassiz, British Columbia, \\ VOM 1A0, Canada
}

\begin{abstract}
Excised shoot tips of sweet potato (Ipomoea babatas L.) were incubated in $\mathrm{H}_{2} \mathrm{O}_{2}$ or $\mathrm{NaCl}$ aqueous solution for $24 \mathrm{~h}$ or $48 \mathrm{~h}$ prior to a 3 -day chilling at $2.5^{\circ} \mathrm{C}$. Severity of chilling injury was visually observed during a post-chilling 7 -day recovery at $21^{\circ} \mathrm{C}$, and scored at 0 to 5 (none to most severe injury). In the first experiment, when cv. Purple (PUR) sweet potato shoots were subjected to 3-day chilling at $2.5^{\circ} \mathrm{C}$, a $48 \mathrm{~h}$ pre-treatment of $150 \mathrm{mM} \mathrm{H}_{2} \mathrm{O}_{2}$ under $16 \mathrm{~h}$ photoperiod reduced chilling injury, but $\mathrm{H}_{2} \mathrm{O}_{2}$ showed no effect under $8 \mathrm{~h}$ photoperiod. An increase of Oxygen Radical Absorbance Capacity (ORAC) occurred two days after recovery at room temperature, and such increase in ORAC was negatively correlated with the severity of chilling injury symptoms observed after seven days at room temperature, indicating the possible protective nature of antioxidants. Because $\mathrm{H}_{2} \mathrm{O}_{2}$-reduced chilling injury occurred only on those pre-treated with $16 \mathrm{~h}$ photoperiod, $16 \mathrm{~h}$ was employed in subsequent $\mathrm{NaCl}$ experiments. In the second experiment, 4 cvs were used: Ace of Spades (ACE), B18, Purple (PUR), and Toka Toka Gold (TTG). Each cv formed a 3 x 2 factorial experiment: $\mathrm{NaCl}$ (0 mM, 200 $\mathrm{mM}$ or $400 \mathrm{mM}$ ) and incubation duration (24h or $48 \mathrm{~h}$ ). The effects of $\mathrm{NaCl}$ depended on cultivar (cv). $\mathrm{NaCl}$ at $200 \mathrm{mM}$ reduced chilling injury more for ACE than $\mathrm{B} 18$ and PUR, but $\mathrm{NaCl}$ increased the injury of TTG. The $\mathrm{NaCl}$ effects also depended on incubation duration ( $24 \mathrm{~h}$ or $48 \mathrm{~h}$ ). Across 4 cvs the most beneficial $\mathrm{NaCl}$ treatment was $200 \mathrm{mM} \mathrm{NaCl}$ for 24h. In view of these results, both pre-treatments of $\mathrm{H}_{2} \mathrm{O}_{2}$ and $\mathrm{NaCl}$ reduced chilling injury of sweet potato shoots, suggesting that moderate stress imposed as a pre-treatment increased plant tolerance to subsequent chilling under specific conditions.
\end{abstract}

Key Words: Antioxidant, stress tolerance, photoperiod, pre-treatment, moderate stress.

\section{INTRODUCTION}

Crop plants are subject to various stresses throughout their life cycles. A wide range of abiotic and biotic stresses can result in generation of reactive oxygen species including $\mathrm{H}_{2} \mathrm{O}_{2}$ [1]. Excessive levels of $\mathrm{H}_{2} \mathrm{O}_{2}$ may lead to cell death, but plants possess a host of antioxidant mechanisms, both enzymatic and non-enzymatic, by which $\mathrm{H}_{2} \mathrm{O}_{2}$ is removed from the cells. Hydrogen peroxide $\left(\mathrm{H}_{2} \mathrm{O}_{2}\right)$ is one of the key signaling compounds that play a role in sensing environmental stress and triggering biochemical and physiological responses to such stimuli [2]. Within a certain range, low concentration of $\mathrm{H}_{2} \mathrm{O}_{2}$ leads to adaptation of crop plants to subsequent stresses. If endogenous $\mathrm{H}_{2} \mathrm{O}_{2}$ leads to stress tolerance, then it may be possible to use exogenous $\mathrm{H}_{2} \mathrm{O}_{2}$ to acclimatize crop plants for various stresses [3].

Among environmental stresses, temperature and salt may be considered the most common in view of climate change [3]. Chilling injury commonly occurs in plants indigenous to tropical and subtropical climates when exposed to temperatures below $12^{\circ} \mathrm{C}$ for a duration exceeding a critical period of time [4]. Heat shock either before or after chilling can reduce

*Address correspondence to this author at the Pacific Agri-Food Research Centre, Agriculture and Agri-Food Canada, P. O. Box 1000, Agassiz, British Columbia, V0M 1A0, Canada; Tel: (604)-796-1713; Fax: (604)-7960359; E-mail: linw@agr.gc.ca subsequent injury, and heat shock significantly increased 1,1-diphenyl-2-picrylhydrazyl(DPPH)-radical scavenging activity [5]. Such an increase in antioxidant activity appears to be correlated with heat shock-induced chilling tolerance in rice seedlings. These findings provide evidence that one stress (e.g. heat shock) can increase the tolerance to another (e.g. chilling). It is likely that such a stress results in production of $\mathrm{H}_{2} \mathrm{O}_{2}$, which in turn activates a mitogen-activated protein kinase (MAPK) cascade that mediates tolerance to various stresses [1]. Our preliminary data and results of others indicated that pre-treatment with exogenous $\mathrm{H}_{2} \mathrm{O}_{2}$ was able to alleviate subsequent chilling injury under certain conditions [6-9]. Salt stress induced accumulation of endogenous $\mathrm{H}_{2} \mathrm{O}_{2}$, similar to chilling [10].

Sweet potato is a major food root crop [11]. Recently sweet potato leaves have received attention as a food because of their high polyphenolic content [12]. Chilling injury has been mostly studied on sweet potato roots [13], but rarely on leaves or shoots. We used sweet potato shoots as a model system for studying chilling injury, because they are easily propagated vegetatively, grow fast in the greenhouse and provide a good source of material for frequent experiments. Our study was designed to evaluate the beneficial effects of $\mathrm{H}_{2} \mathrm{O}_{2}$ and $\mathrm{NaCl}$ on chilling tolerance of sweet potato shoots and to explore the potential role of antioxidants in $\mathrm{H}_{2} \mathrm{O}_{2^{-}}$ related chilling tolerance. 


\section{MATERIALS AND METHODS}

\section{Plant Materials}

Four cultivars of sweet potato (Ipomoea babats L.) plants were used in this study: Ace of Spades (ACE), B18, Purple (PUR) and Toka Toka Gold (TTG). Plants were propagated by rooting shoot tip cuttings, and then grown as stock plants in $30 \mathrm{~cm}$ (diameter) hanging baskets in the greenhouse under natural light. During the low light period of October to March, natural light of less than $12 \mathrm{~h} 15$ min was supplemented with high pressure sodium lighting (0600-2200). Air temperature was set to maintain a range of $22-26^{\circ} \mathrm{C}$. Uniform shoot tips were excised from stock plants and immediately used as experimental material. There were two experiments: one with $\mathrm{H}_{2} \mathrm{O}_{2}$ and the other with $\mathrm{NaCl}$ treatments.

\section{$\mathrm{H}_{2} \mathrm{O}_{2}$ Experiment}

Terminal shoots, $15-20 \mathrm{~cm}$ long, with one to three fully expanded leaves were selected for uniformity and excised from stock plants of $\mathrm{cv}$. PUR. On the initial day of experiment (day 0), 48 shoots were excised, with the cut surface submerged in and incubated with de-ionized water in $50 \mathrm{ml}$ test tubes. Half the population was placed in a growth chamber with air temperature set at $21^{\circ} \mathrm{C}$ and $8 \mathrm{~h}$ photoperiod (0800-1600 at $\left.83 \mu \mathrm{E} / \mathrm{m}^{2} / \mathrm{sec}\right)$, and the other half in another growth chamber with $21^{\circ} \mathrm{C}$ and $16 \mathrm{~h}$ photoperiod (0800-1600 at $83 \mu \mathrm{E} / \mathrm{m}^{2} / \mathrm{sec}, 1601-2400$ at $10 \mu \mathrm{E} / \mathrm{m}^{2} / \mathrm{sec}$ ). After two days in the photoperiodic conditionings (day 2), half of the population was incubated in $150 \mathrm{mM} \mathrm{H}_{2} \mathrm{O}_{2}$ and the other half remained in de-ionized water (control). The experiment of 4 treatments was arranged as a factorial of 2 photoperiods with and without $\mathrm{H}_{2} \mathrm{O}_{2}$ treatment. After two days in $\mathrm{H}_{2} \mathrm{O}_{2}$ (day 4), all shoots were incubated in de-ionized water and were placed in a cooler at $2.5^{\circ} \mathrm{C}$ for 3 days with no light. After three days in cooler (day 7), all plants were moved to the third growth chamber for recovery at $21^{\circ} \mathrm{C}$ and $12 \mathrm{~h}$ photope$\operatorname{riod}\left(0600-1800\right.$ at $\left.90 \mu \mathrm{E} / \mathrm{m}^{2} / \mathrm{sec}\right)$. After seven days at $21^{\circ} \mathrm{C}$ (day 14), the experiment ended. Injury of each shoot was visually observed and recorded on days 4, 7, 9 and 14 of the experiment, with $10,8,6$ and 4 shoots available per treatment respectively. The reduction in available shoots resulted from destructive sampling for ORAC measurement (below). The severity of injury, either caused by $\mathrm{H}_{2} \mathrm{O}_{2}$ or chilling, was visually observed and scored with a score of 0 to 5 . Shoots of injury index 0 had no injury; index 1 had only the first signs of injury, including leaf wilting or discolouration at the edge of at least one leaf; index 2 had more severe injury, wilting and chlorosis in a single area or less injury spread to 2 leaves; index 3 had moderate injury of 2 leaves; index 4 had 3 leaves or with severe symptoms; and index 5 had severe injury or death of the whole shoot.

\section{Oxygen Radical Absorbance Capacity (ORAC) Meas- urement}

On days $0,2,4,7$ and 9, two shoots per treatment were removed from the $\mathrm{H}_{2} \mathrm{O}_{2}$ experiment for ORAC measurement based on the method of Cao [14] with some modifications. Samples were run on a Varian (Palo Alto, CA, USA) Cary Eclipse fluorescence spectrophotometer with a Peltierthermostated multicell holder and temperature controller. Fluorescein (Sigma-Aldrich, Oakville, ON, Canada) was used as the fluorescent reagent, with AAPH (2,2'-Azobis (2- amidinopropane) dihydrochloride, Wako Chemicals, Richmond, VA, USA) as the free radical generator and Trolox (6Hydroxy-2,5,7,8-tetramethylchromane-2-carboxylic acid, Sigma-Aldrich, Oakville, ON, Canada) as the standard, in final concentrations of $0.630 \mu \mathrm{M}, 6 \mathrm{mM}$, and $1 \mu \mathrm{M}$, respectively. Finely chopped leaf samples were accurately weighed into centrifuge tubes and homogenized with $\mathrm{pH} 7.0$ phosphate buffer for $1 \mathrm{~min}$. The tubes were then centrifuged at $20,000 \mathrm{x} \mathrm{g}$ and $4{ }^{\circ} \mathrm{C}$ for $20 \mathrm{~min}$. Extracted samples $(20 \mu \mathrm{l})$ were used for the ORAC assay. Results were expressed as $\mu$ mol Trolox Equivalent (TE) per gram of fresh sample. Once two leaves of a shoot were sampled for ORAC assay, these shoots were no longer available for evaluation of injury index.

\section{NaCl Experiments}

The procedures for $\mathrm{NaCl}$ experiments were similar to the $\mathrm{H}_{2} \mathrm{O}_{2}$ experiment (above). Twenty four (24) terminal shoots $15-20 \mathrm{~cm}$ long with one to three fully expanded leaves were selected for uniformity and excised from greenhouse grown stock plants of each of 4 cvs: ACE, B18, PUR and TTG. On the initial day of experiment (day 0) the cut surface of each shoot was submerged in and incubated with de-ionized water in $50 \mathrm{ml}$ test tubes that were immediately placed in a growth chamber with air temperature set at $21^{\circ} \mathrm{C}$ and $16 \mathrm{~h}$ photope$\operatorname{riod}\left(0800-1600\right.$ at $83 \mu \mathrm{E} / \mathrm{m}^{2} / \mathrm{sec}, 1601-2400$ at $10 \mu \mathrm{E} / \mathrm{m}^{2} /$ sec) until all shoots recovered from wilting. They were separated into three incubation treatments: (1) $200 \mathrm{mM} \mathrm{NaCl}$ for $24 \mathrm{~h}$ or $48 \mathrm{~h}$, (2) $400 \mathrm{mM} \mathrm{NaCl}$ for $24 \mathrm{~h}$ or $48 \mathrm{~h}$, and (3) deionized water. After one day in growth chamber (day 1), 4 shoots of each of $200 \mathrm{mM}$ or $400 \mathrm{mM} \mathrm{NaCl}$ treatment were transferred into de-ionized water ( $24 \mathrm{~h}$ duration). After two days in growth chamber (day 2), another 4 shoots of each of $200 \mathrm{mM}$ or $400 \mathrm{mM} \mathrm{NaCl}$ treatment were transferred into de-ionized water (48h duration). This arrangement constituted a factorial experiment of three $\mathrm{NaCl}(0 \mathrm{mM}, 200 \mathrm{mM}$, or $400 \mathrm{mM} \mathrm{NaCl})$ treatments for two incubation lengths $(24 \mathrm{~h}$ or $48 \mathrm{~h}$ ), each having 4 shoots. All shoots were then placed in a cooler at $2.5^{\circ} \mathrm{C}$ for 3 days with no light (day 2 - day 5). After three days at $2.5^{\circ} \mathrm{C}$ (day 5), all plants were moved into a growth chamber set at $21^{\circ} \mathrm{C}$ and $12 \mathrm{~h}$ photoperiod $(0600$ 1800 at $90 \mu \mathrm{E} / \mathrm{m}^{2} / \mathrm{sec}$ ) to recover. After seven days of recovery (day 12), the experiments ended. Injury of each shoot was visually evaluated and index recorded on 4 occasions: days 2, 5, 7 and 12. The injury index of 0 to 5 was used to record each shoot as in the $\mathrm{H}_{2} \mathrm{O}_{2}$ experiment. No ORAC measurements were made in the $\mathrm{NaCl}$ experiments.

\section{Statistical Treatment}

Each shoot was treated as an experimental unit. Analysis of variance was carried out with Proc GLM of SAS package (SAS version 9.1.3, SAS Institute, Cary, NC, USA). The average value of ORAC was correlated with the average value of injury index in each treatment in the $\mathrm{H}_{2} \mathrm{O}_{2}$ experiment.

\section{RESULTS AND DISCUSSION}

\section{$\mathrm{H}_{2} \mathrm{O}_{2}$ Experiment}

Temporary wilting was observed with $150 \mathrm{mM} \mathrm{H} \mathrm{H}_{2} \mathrm{O}_{2}$ incubation, but all shoots recovered from wilting before chilling treatment began (day 4). No other toxic effect of 
$\mathrm{H}_{2} \mathrm{O}_{2}$ was observed on non-chilled shoots, similar to our previous data [9]. Upon immediate removal from 3-day chilling (day 7), $\mathrm{H}_{2} \mathrm{O}_{2}$ reduced the severity of chilling injury from 4.6 to $3.1(\mathrm{n}=16, \mathrm{P}<0.0001)$. Two days after removal from cooler into $12 \mathrm{~h}$ photoperiod growth chamber for recovery (day 9), $150 \mathrm{mM} \mathrm{H}_{2} \mathrm{O}_{2}$ reduced chilling index from 4.3 to 3.2 $(\mathrm{n}=12, \mathrm{P}=0.0002)$ and $16 \mathrm{~h}$ photoperiod also reduced the index from 4.3 to $3.3(n=12, P=0.0008)$. After one week in recovery (day 14), chilling injury was reduced by a combination of $150 \mathrm{mM} \mathrm{H} \mathrm{H}_{2} \mathrm{O}_{2}$ and $16 \mathrm{~h}$ photoperiod (Table 1). The observed beneficial effects of $150 \mathrm{mM} \mathrm{H}_{2} \mathrm{O}_{2}$ on chilling tolerance of sweet potato shoots are similar to those previously observed in seedlings of corn [15], mungbean [6, 8] and tomato [7]. In many of our previous experiments, the effect of $\mathrm{H}_{2} \mathrm{O}_{2}$ varied from one experiment to the next [9]. The interaction between $\mathrm{H}_{2} \mathrm{O}_{2}$ and photoperiod in affecting chilling tolerance is evident in this study (Table 1). The observed interaction between $\mathrm{H}_{2} \mathrm{O}_{2}$ and photoperiod may have been one of the main causes for inconsistent results in our preliminary experiments (unpublished data), where the excised leaves or shoots displayed various degrees of $\mathrm{H}_{2} \mathrm{O}_{2}$ beneficial effect. This may have been due to the fact that those shoots were taken directly from the stock plants grown in the greenhouse under natural daylight and used immediately in chilling treatments without any pre-conditioning at a specific photoperiod. This shows that the state of the plant materials may vary substantially as a result of fluctuating greenhouse conditions, especially in respect to varying photoperiods and levels of irradiation in studies on chilling effects. In this study, the importance of $16 \mathrm{~h}$ photoperiod during $\mathrm{H}_{2} \mathrm{O}_{2}$ incubation prior to chilling treatment was identified, although the mechanisms of photoperiod and light intensity effects in chilling tolerance remain unknown. It was observed in another study that $24 \mathrm{~h}$ lighting prior to chilling enhanced tolerance. Continuous illumination induced minimal chilling damage to maize seedlings, and dark-grown ones suffered the maximum damage [16]. It was further observed that $2 \mathrm{~h}$ or $4 \mathrm{~h}$ interruption each day during 3-day darkness reduced the injury to the level of $24 \mathrm{~h}$-illumination, demonstrating the effect of long photoperiod (i.e. dark interruption). These observations were opposite to another study where a short photoperiod induced cold tolerance [17]. As to light intensity, it was likely that low light intensity in the growth chamber where $\mathrm{H}_{2} \mathrm{O}_{2}$ pre-treatment was administered decreased chilling injury as observed in Coleus blumei Benth [18]. In our study, however, the PAR (light intensity) is almost equal between $8 \mathrm{~h}$ and $16 \mathrm{~h}$ growth chambers. Therefore, the interaction between $16 \mathrm{~h}$ and $\mathrm{H}_{2} \mathrm{O}_{2}$ is most likely due to $16 \mathrm{~h}$ photoperiod rather than due to light intensity (i.e. PAR). Our study illustrates the importance of selecting a specific lighting condition (i.e. photoperiod and PAR) for effective evaluation of chilling injury.

\section{ORAC Measurements}

In $\mathrm{H}_{2} \mathrm{O}_{2}$ experiment, there was no effect of $\mathrm{H}_{2} \mathrm{O}_{2}$, photoperiod or their interaction on ORAC measured on days $0,2,4$, and 7 (data not shown). Nevertheless, the high level of ORAC measured on day 9 ( 2 days in recovery) coincided with low injury index observed on day 14 (7 days in recovery; Table 1). This study also confirms our preliminary results that high level of ORAC is not always obviously related to low degree of visible injury symptoms. Although the dif- ference between treatments was not statistically significant, the high ORAC on day 9 was negatively related to low chilling injury index observed on day 14 (Table 1). The lag between the change in ORAC and visual injury symptoms, which is not easily identified, could obscure direct correlations. Our results were similar to the results of others in that the increase of antioxidant activity occurred after the transfer to room temperature for 3 days of non-cured sweet potato roots stored at $5^{\circ} \mathrm{C}$ for 2 or 4 weeks [19]. Our correlation of ORAC values at one date with injury indexes at another date during a 3-day chilling followed by a 7-day recovery is one of several possible comparisons. It has been recognized that high levels of antioxidants correspond with high chilling tolerance of cucumber seedlings [20]. The high level of ORAC on day 9 which occurred before the expression of chilling injury on day 14 (Table 1) indicates the possible protective nature of ORAC activity, although such causal link was questioned according to the results for zucchini squash [21]. This study illustrates ORAC may be an early indicator for visible symptoms of chilling injury. However, the timing of ORAC measurement may require further investigation.

Table 1. Injury Index and Oxygen Radical Absorbance Capacity (ORAC) Measures of Chilled Sweet Potato Shoots cv. Purple After 7 and 3 Days in Recovery, Respectively, Following 3-Day Pre-Treatment and 3Day Chilling. Injury Index $(n=4)$ and ORAC $(n=2)$

\begin{tabular}{|c|c|c|}
\hline Treatment & Injury Index & ORAC \\
\hline \hline $8 \mathrm{~h}-0 \mathrm{mM}$ & 4.8 & 54.8 \\
\hline $8 \mathrm{~h}-150 \mathrm{mM}$ & 4.8 & 34.5 \\
\hline $16 \mathrm{~h}-0 \mathrm{mM}$ & 4.5 & 52.2 \\
\hline $16 \mathrm{~h}-150 \mathrm{mM}$ & 3.0 & 64.5 \\
\hline $\mathrm{GLM}$ & $\mathrm{Pr}>\mathrm{F}$ & $\mathrm{Pr}>\mathrm{F}$ \\
\hline Photoperiod & 0.0068 & 0.1030 \\
\hline $\mathrm{H}_{2} \mathrm{O}_{2}$ & 0.0306 & 0.5743 \\
\hline $\mathrm{P} \times \mathrm{H}$ & 0.0306 & 0.0671 \\
\hline $\mathrm{SE}$ & 0.31 & 6.54 \\
\hline
\end{tabular}

\section{NaCl Experiment}

Preliminary experiments showed that mild wilting was caused by $\mathrm{NaCl}$, but most shoots recovered to some degree before chilling treatment was started. Only chilled shoots were included in this experiment due to the limitation of growth chamber space. After seven days in recovery (day 12), a difference in injury index caused by 3-day exposure to $2.5^{\circ} \mathrm{C}$ was observed $(\mathrm{P}<0.0001)$. From the $\mathrm{H}_{2} \mathrm{O}_{2}$ experiment, the chilling tolerance was most effectively observed when sweet potato shoots were pre-conditioned under16hphotoperiod in the growth chamber. Therefore, the $\mathrm{NaCl}$ treatments were also conducted under16h photoperiod. Both $\mathrm{H}_{2} \mathrm{O}_{2}$ and $\mathrm{NaCl}$ experiments showed that chilling tolerance 
could be effectively observed when sweet potato shoots were pre-conditioned with a $16 \mathrm{~h}$ photoperiod.

There were two interactions in the $\mathrm{NaCl}$ pre-treatment experiment; $\mathrm{NaCl} \times$ cultivar $(\mathrm{P}<0.0001)$ and $\mathrm{NaCl} \times$ treatment duration $(\mathrm{P}=0.0059)$. For the $\mathrm{NaCl} \times$ cultivar interaction, $200 \mathrm{mM} \mathrm{NaCl}$ reduced chilling injury more in ACE than in $\mathrm{B} 18$ and PUR, but $\mathrm{NaCl}$ increased the injury in TTG (Table 2). Among the two chilling sensitive cvs (ACE and B18), it was unexpected that the lowest injury index of 3.9 was observed with ACE treated with $200 \mathrm{mM} \mathrm{NaCl}$ for $24 \mathrm{~h}$. When ACE was not treated, the injury index was very high in preliminary experiments and shoots often failed to survive 3-day chilling at $2.5^{\circ} \mathrm{C}$, having an injury index close to 5.0 (Lin, unpublished data). Cultivar B18 was observed to have an index of 4.8 in control, and 4.1 when treated with 200 $\mathrm{mM} \mathrm{NaCl}$. For the two tolerant cvs (PUR and TTG), PUR had the lowest injury index of 2.6 with $200 \mathrm{mM} \mathrm{NaCl}$ for $24 \mathrm{~h}$ (compared to the control of 3.3) whereas, $\mathrm{NaCl}$ had a detrimental effect on TTG on day 12. Control treatment on TTG had an injury index of 3.3 , while $\mathrm{NaCl}$ pre-treatment indexes were 3.8 or 4.3 . This indicates that the tolerant $\mathrm{cv}$. TTG did not need $\mathrm{NaCl}$ pre-treatment to tolerate chilling stress or it was sensitive to $\mathrm{NaCl}$ stress. For the $\mathrm{NaCl}$ x duration interaction the most beneficial treatment was $200 \mathrm{mM}$ $\mathrm{NaCl}$ incubation for $24 \mathrm{~h}$, and the second lowest injury was observed with a pre-treatment of $200 \mathrm{mM} \mathrm{NaCl}$ for $48 \mathrm{~h}$ for all 4 cvs (Table 3 ). It should be noted that to maintain comparable time for the injury measurement, the $24 \mathrm{~h}$ incubation was followed by another $24 \mathrm{~h}$ in de-ionized water prior to chilling stress while $48 \mathrm{~h}$ incubation was ended immediately before entering the chilling treatment. Whether the $24 \mathrm{~h}$ gap with de-ionized water made any difference as compared to $48 \mathrm{~h}$ incubation ending immediately before entering the $2.5^{\circ} \mathrm{C}$ cooler could not be determined by this experimental design. It has been recognized that salt stress is associated with oxidative stress and increased $\mathrm{H}_{2} \mathrm{O}_{2}$ level in plant tissue [10]. It is reasonable to assume that $\mathrm{NaCl}$ incubation also caused generation of $\mathrm{H}_{2} \mathrm{O}_{2}$ in vivo and resulted in a similar reduction in chilling injury as exogenous $\mathrm{H}_{2} \mathrm{O}_{2}$ pre-treatment did.

\section{SUMMARY}

This study illustrated that a pre-treatment of $\mathrm{H}_{2} \mathrm{O}_{2}$ under $16 \mathrm{~h}$ photoperiod increased the tolerance of sweet potato shoots to a subsequent chilling stress. It is likely that exogenous $\mathrm{H}_{2} \mathrm{O}_{2}$ serves as a signal and activates physiological changes leading to chilling tolerance. The same reasoning can be applied to $\mathrm{NaCl}$-induced chilling tolerance. Application of $\mathrm{NaCl}$ acts as a stress stimulus and produces endogenous active oxygen species, including $\mathrm{H}_{2} \mathrm{O}_{2}$, which in turn activates a mechanism similar to exogenous application of $\mathrm{H}_{2} \mathrm{O}_{2}$. All data show that a moderate stress can increase the tolerance to subsequent stress in a cross-talk mechanism [10]. Further studies are necessary to define a specific set of environmental conditions under which a range of concentrations of exogenous $\mathrm{H}_{2} \mathrm{O}_{2}$ or $\mathrm{NaCl}$ can be effectively used as protective agents against chilling stress. Both $\mathrm{H}_{2} \mathrm{O}_{2}$ and $\mathrm{NaCl}$ are non-toxic, natural compounds, and in low concentrations they are suitable for agricultural uses yet are not a severe environmental concern. Our results illustrate that moderate stress $\left(\mathrm{H}_{2} \mathrm{O}_{2}\right.$ and $\left.\mathrm{NaCl}\right)$ during production could reduce postharvest loss due to chilling injury. The common use of heat shock during post-harvest requires extra equipment whereas
$\mathrm{H}_{2} \mathrm{O}_{2}$ and $\mathrm{NaCl}$ only require low cost chemical treatment to reduce chilling injury. In addition to reducing chilling injury, pre-treatments of $\mathrm{H}_{2} \mathrm{O}_{2}$ or $\mathrm{NaCl}$ may also influence crop quality (i.e. high vitamin C) for human health benefits [22].

Table 2. Injury Index of 3-Day Chilled Sweet Potato Shoots Affected by an Interaction of $\mathrm{NaCl}$ Pre-Treatment and Cultivars $(\mathrm{n}=8, \mathrm{Pr}<0.0001, \mathrm{SE}=0.26)$. Index was Measured After 7-Day Recovery at Room Temperature

\begin{tabular}{|c|c|c|c|c|}
\hline NaCl & Ace of Spades & B18 & Purple & Toka Toka Gold \\
\hline \hline $0 \mathrm{mM}$ & 5.0 & 4.8 & 3.4 & 3.3 \\
\hline $200 \mathrm{mM}$ & 3.9 & 4.1 & 2.6 & 3.8 \\
\hline $400 \mathrm{mM}$ & 5.0 & 4.9 & 4.3 & 4.3 \\
\hline
\end{tabular}

Table 3. Injury Index of 3-Day Chilled Sweet Potato Shoots was Reduced by an Interaction of $\mathrm{NaCl}$ PreTreatment and Length of Incubation $(n=16$, $\operatorname{Pr}=0.0059, \mathrm{SE}=0.11$ ). Index was Measured After 7Day Recovery at Room Temperature

\begin{tabular}{|c|c|c|}
\hline $\mathrm{NaCl}$ & $\mathbf{2 4 h}$ - Incubation & $\mathbf{4 8 h}$ - Incubation \\
\hline \hline $0 \mathrm{mM}$ & 5.0 & 5.0 \\
\hline $200 \mathrm{mM}$ & 3.3 & 4.5 \\
\hline $400 \mathrm{mM}$ & 5.0 & 4.9 \\
\hline
\end{tabular}

\section{ACKNOWLEDGEMENT}

Authors thank Tom Forge and Grant Kowalenko for critical review during manuscript preparation. Agassiz Contribution No. 785 .

\section{REFERENCES}

[1] Neill SJ, Desikan R, Clarke A, Hurst RD, Hancock JT. Hydrogen peroxide and nitric acid as signalling molecules in plants. J Exp Bot 2002; 53(372): 1237-47.

[2] Mittler R. Oxidative stress, antioxidants and stress tolerance. Trends Plant Sci 2002; 7(9): 405-10.

[3] Uchida A, Takabe T, Takabe T, Jagendorf AT. In: Rai AK, Takabe $\mathrm{T}$, Eds. Induction of biosynthesis of osmoprotectants in higher plants by hydrogen peroxide and its application to agriculture. Abiotic Stress Tolerance in Plants, Springer, The Netherlands 2006; 153-9.

[4] Saltveit ME. Chilling injury is reduced in cucumber and rice seedlings and in tomato pericarp discs by heat-shocks applied after chilling. Postharvest Biol Technol 2001; 21(2): 167-77.

[5] Kang HM, Saltveit ME. Antioxidant enzymes and DPPH-radical scavenging activity in chilled and heat-shocked rice (Oryza sativa L.) seedling radicles. J Agric Food Chem 2002; 50(3): 513-8.

[6] $\mathrm{Yu}$ CW, Murphy TM, Sung WW, Lin $\mathrm{CH} . \mathrm{H}_{2} \mathrm{O}_{2}$ treatment induces glutathione accumulation and chilling tolerance in mung bean. Funct Plant Biol 2002; 29(9): 1081-7.

[7] Al-Haddad JM, Al-Jamali AF. Effect of $\mathrm{H}_{2} \mathrm{O}_{2}$ and ethephon spray on seedling chilling tolerance in three tomato cultivars. Food Agric Environ 2003; 1(3/4): 219-21.

[8] Lin WC, Saltveit ME. Oxidative stress and chilling injury of mungbean seedlings. Acta Hort 2005; 682: 1293-6.

[9] Lin WC, Block GS. Beneficial effects of using hydrogen peroxide in crop production systems. Paper presented at the International 
Conference on Sustainable Agriculture for Food, Energy and Industry 2008 (ISCA2008), Sapporo, Japan, July 2-6, 2008.

[10] Dat J, Vandenabeele S, Vranova E, Van Montagu M, Inze D, Van Breusegem F. Dual action of active oxygen species during plant stress responses. Cell Mol Life Sci 2000; 57(5): 779-95.

[11] Philpott M, Gould KS, Markham KR, Lewthwaite SL, Ferguson LR. Enhanced coloration reveals high antioxidant potential in new sweet potato cultivars. J Sci Food Agric 2003; 83(10): 1076-82.

[12] Chen CM, Li SC, Lin YL, Hsu CY, Shieh MJ, Liu JF. Consumption of purple sweet potato leaves modulates human immune response: T-lymphocyte functions, lytic activity of natural killer cell and antibody function. World J Gastroenterol 2005; 11(37): 577781.

[13] Wilson PW, Picha DH, Ameny M. The effect of chilling injury on the processing of sweet potato for puree. Acta Hort 1994; 380: 4215.

[14] Cao G, Alessio HM, Cutler RG. Oxygen-radical absorbance capacity assay for antioxidants. Free Radic Biol Med 1993; 14(3): 303-11.

[15] Prasad TK, Anderson MD, Stewart CR. Acclimation, hydrogen peroxide, and abscisic acid protect mitochondria against irreversible chilling injury in maize seedlings. Plant Physiol 1994; 105(2): 619-27.
[16] Grishenkova NN, Lukatkin AS, Stanys VA, Duchovskis PV. Light effects on chilling adoptation of maize seedlings. Russian Agric Sci 2006; 10: 1-3.

[17] Johnson JR, Havis JR. Photoperiod and temperature effects on root cold acclimation. J Am Soc Hort Sci 1977; 102(3): 306-8

[18] Krizek DT, Semeniuk P, Holine HE, Mirecki RM, Abbott JA. Chilling injury in coleus as influenced by photosynthetically active radiation, temperature and abscisic acid pre-treatment. I. Morphological and physiological responses. Plant Cell Environ 1985; 8(2): 135-42.

[19] Padda MS, Picha DH. Effect of low temperature storage on phenolic composition and antioxidant activity of sweet potato. Postharvest Biol Technol 2008; 47(2): 176-80.

[20] Kang HM, Saltveit ME. Effect of chilling on antioxidant enzymes and DPPH-radical scavenging activity of high- and low-vigour cucumber seedling radicles. Plant Cell Environ 2002; 25(10): 1233-6.

[21] ZhengY, Fung RWM, Wang SY, Wang CY. Transcription levels of antioxidative genes and oxygen radical scavenging enzyme activities in chilled zucchini squash in response to superatmospheric oxygen. Postharvest Biol Technol 2008; 47(2): 151 -8.

[22] Krauss S, Schnitzler WH, Grassmann J, Woikte M. The influence of different electrical conductivity values in a simplified recirculating soilless system on inner and outer fruit characteristics of tomato. J Agric Food Chem 2006; 54(2): 441-8.

(C) Lin and Block; Licensee Bentham Open.

This is an open access article licensed under the terms of the Creative Commons Attribution Non-Commercial License (http://creativecommons.org/licenses/ by-nc/3.0/) which permits unrestricted, non-commercial use, distribution and reproduction in any medium, provided the work is properly cited. 